Research article

\title{
THE IMPACT OF DOUBLE LAYER MEMBRANE TECHNIQUE ON BONE REGENERATION IN POSTEXTRACTION ALVEOLI - A PATHOHISTOLOGICAL EXPERIMENTAL STUDY IN DOGS
}

\author{
DUBOVINA Dejan ${ }^{1}$, BUBALO Marija ${ }^{2}$, MIHAILOVIĆ Branko ${ }^{1}$, TATIĆ Zoran ${ }^{2}$, \\ MARINKOVIĆ Darko ${ }^{3}$, BUKUMIRIĆ Zoran ${ }^{4}$, ĐORĐEVIĆ Filip ${ }^{1 *}$, LAZIĆ Zoran ${ }^{2}$
}

${ }^{1}$ Faculty of Medicine, University of Pristina, Kosovska Mitrovica, Serbia; ${ }^{2}$ Faculty of Medicine-Military Medical Academy, Defence University, Belgrade, Serbia; ${ }^{3}$ Faculty of Veterinary Medicine, University of Belgrade, Belgrade, Serbia; ${ }^{4}$ Faculty of Medicine, University of Belgrade, Belgrade, Serbia

(Received 14 February, Accepted 25 September 2020)

\begin{abstract}
Post extraction alveolar ridge preservation is a preventive oral surgical procedure aimed to preserve the dimensions of the alveolar ridge after removal of the teeth. According to literature data, the utilization of guided bone regeneration for this purpose is absolutely justified. The aim of this study was to examine the effect of resorbable collagen membranes placed in two layers in respect to the application of membranes placed in one layer to the degree of bone regeneration after a tooth extraction. This experimental study was conducted on six adult dogs. In the first phase all four premolars were extracted on both sides in the lower jaw. After the volume-standardisation with bone drill, three post extraction alveoli were filled with bone substitute of equine origin and then covered with: collagen bioresorbable membrane of porcine origin; collagen bioresorbable membrane of equine origin; pericardial bioresorbable membrane of equine origin. The membranes on the left side were placed in single-layer and on the right side in double-layer manner. After different monitoring periods, histopathological analysis of the samples taken from the experimental regions was performed. A different degree of bone regeneration was achieved between experimental regions in which membranes were placed in one layer and those where membranes were placed in two layers. There was no difference between regions where membranes of different origin were placed in the same manner. The procedure of covering the post extraction alveoli, filled with bone substitute and with resorbable membranes placed in two layers resulted in a higher degree of bone regeneration compared to those where resorbable membranes were placed in one layer.
\end{abstract}

Key words: Guided bone regeneration, double layers membranes, post extraction alveoli

\footnotetext{
*Corresponding author: e-mail: Filip85dj@gmail.com
} 


\section{INTRODUCTION}

Many factors can lead to the loss of alveolar bone, such as periodontal disease, facial trauma, aggressive tooth extraction and other. Although bone tissue has an extensive regenerative potential and can completely renew its original structure and function, the defects that occur often do not heal spontaneously with bone tissue. In order to enable and stimulate regeneration, defects are often filled with bone substitutes [1-3].

Post extraction alveolar ridge preservation is a preventive, pre-prosthetic, oral-surgical procedure aimed to preserve the dimensions of the alveolar ridge after removal of teeth, as to create favourable conditions for the placement of dental implants and prosthetic rehabilitation of the patient. After extraction, it is necessary to preserve somehow the horizontal and vertical dimension of the alveolar ridge, that is, to direct the healing of the post-extraction wound in a desirable direction, toward regeneration rather than reparation. According to the available literature data, the utilization of guided bone regeneration for the purpose of the alveolar ridge preservation after a tooth extraction is absolutely justified [4-22]. In order to solve this problem, the application of barrier membranes is indicated [23].

There are five surgical principles that should be attained in order to achieve the goal of guided bone regeneration: application of the appropriate membrane, achievement of primary soft tissue closure, creation and maintenance of the membrane-protected space, adaptation and stabilization of the membrane to the surrounding bone and adequate length of the healing period [24].

The impact of different collagen membrane thickness on bone regeneration has not been sufficiently studied and the literature data related to this topic are scarce. The placement of multiple layers membrane is aimed to achieve a prolonged barrier effect as well as to stabilize the bioresorbable membranes and bone substitutes. There were attempts to use an experimental three-layered membrane, but the authors do not recommend it for everyday clinical practice [25]. Every single new fact related to this issue represents a significant contribution to improved and better knowledge of bone defects treatment, especially important for implantology practice.

The aim of this study was to examine the effect of resorbable collagen membranes placed in two layers compared to membranes placed in one layer concerning the degree of bone regeneration after a tooth extraction.

\section{MATERIAL AND METHODS}

This experimental study was conducted at the Medical Research Institute of the Military Medical Academy in Belgrade on six adult German Shepherd dogs at an average age of 5.6 years and at an average weight of $24.6 \mathrm{~kg}$. The protocol of this study was approved by the Ethics Committee of the Medical Faculty in Pristina Kosovska Mitrovica, No.05-73/23.01.2013. 
All surgical procedures were preceded by premedication and the surgical treatment itself was performed in dissociative anaesthesia.

As premedication, acepromazine (Combelen) was administered intravenously in a dose of $0.03 \mathrm{ml} / \mathrm{kg}$ and atropine subcutaneously in a dose of $0.01 \mathrm{mg} / \mathrm{kg}$ body weight. Fifteen minutes after premedication, 5\% ketamine chloride was administered intramuscularly, in a dose of $0.3 \mathrm{ml} / \mathrm{kg}$ bodyweight.

\section{The first phase of the experiment}

During the first, surgical phase of the experiment, all four premolars (P1, P2, P3 and P4) were extracted on both sides in the lower jaw. After the sulcus incision and the uplifting of the buccal and lingual mucoperiosteal flaps, the teeth roots were separated in order to achieve atraumatic extraction (Figure 1).

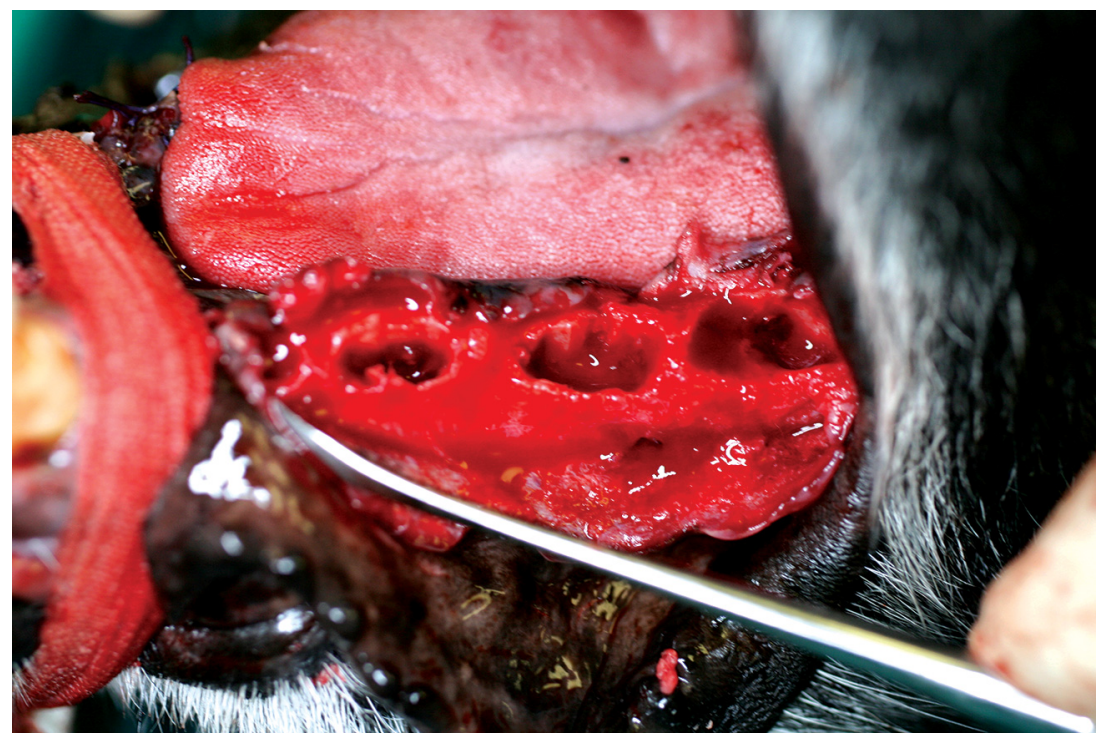

Figure 1. Post-extraction sockets, left side.

Post-extraction alveoli of the first premolar (P1) have been excluded from the study due to a close correlation with the root of the canine tooth. The extraction of the first premolars enabled an easier surgical approach and handling, as well as direct suturing.

Six post-extraction alveoli (P2, P3 and P4, on both sides), were volume-standardized with a $5 \mathrm{~mm} \times 13 \mathrm{~mm}$ bone drill (Nobel Biocare AB, Sweden) and then filled with a bone substitute of equine origin in the form of a $0.5 \mathrm{~mm}$ granules (OSP-OX32, Osteoxenon, Bioteck, Italy).

Immediately after, the extraction alveoli were covered with bioresorbable membranes as per the following schedule: 
Left side (Figure 2):

1. P2-collagen resorbable membrane of porcine origin (Bio-Gide, Geistlich, Switzerland)

2. P3-collagen resorbable membrane of equine origin (Osteoxenon, Bioteck, Italy)

3. P4-pericardium membrane of equine origin (Osteoxenon, Bioteck, Italy)

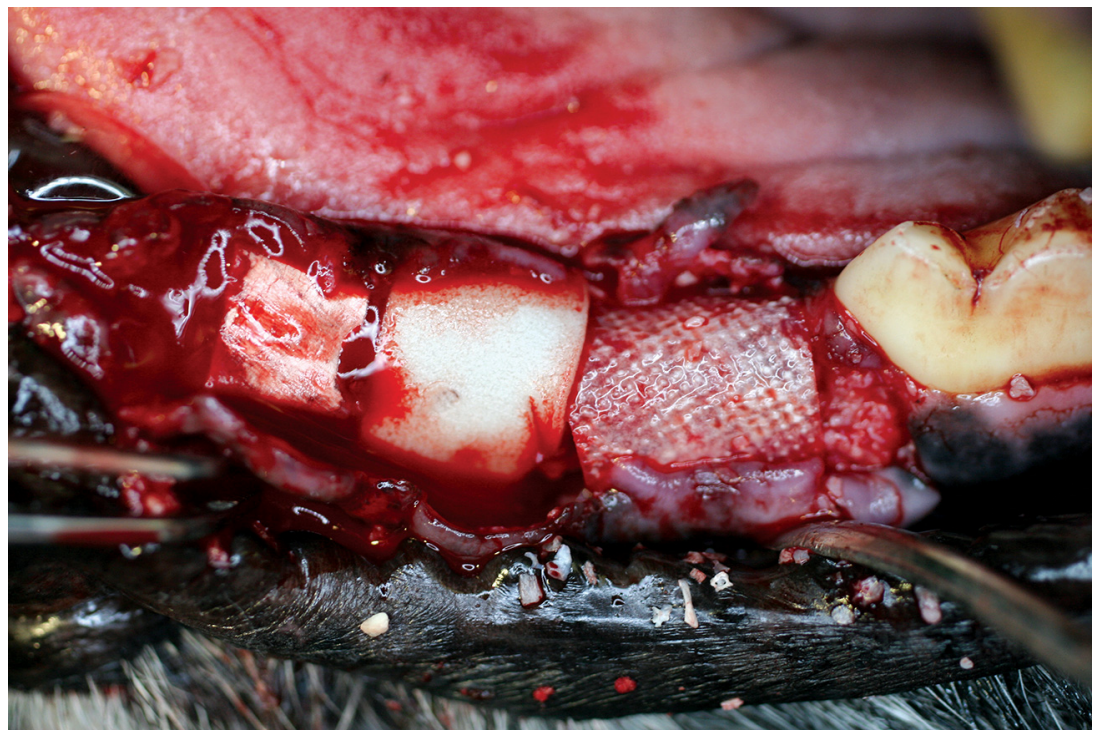

Figure 2. Post-extraction sockets, left side, covered with bioresorbable membranes placed in one layer: P2 - collagen resorbable membrane of porcine origin; P3-collagen resorbable membrane of equine origin; P4-pericardium membrane of equine origin.

Right side (Figure 3):

1. P2-double-layered collagen resorbable membrane of porcine origin (Bio-Gide, Geistlich, Switzerland)

2. P3-double-layered collagen resorbable membrane of equine origin (Osteoxenon, Bioteck, Italy)

3. P4-double-layered pericardium membrane of equine origin (Osteoxenon, Bioteck, Italy)

Each membrane was designed to completely cover the defect and it extended to at least 2-3 $\mathrm{mm}$ from the edges of the defect. Extraction wounds were sewn with individual surgical sutures (Dexon 3.0 Davis \& Gack).

Postoperative antibiotic therapy consisted of an intravenous application of 1.600 .000 IU of crystalline penicillin for two days. The health status control check of the experimental animals was carried out daily. Dogs were kept in separate boxes and fed with mushy food. 


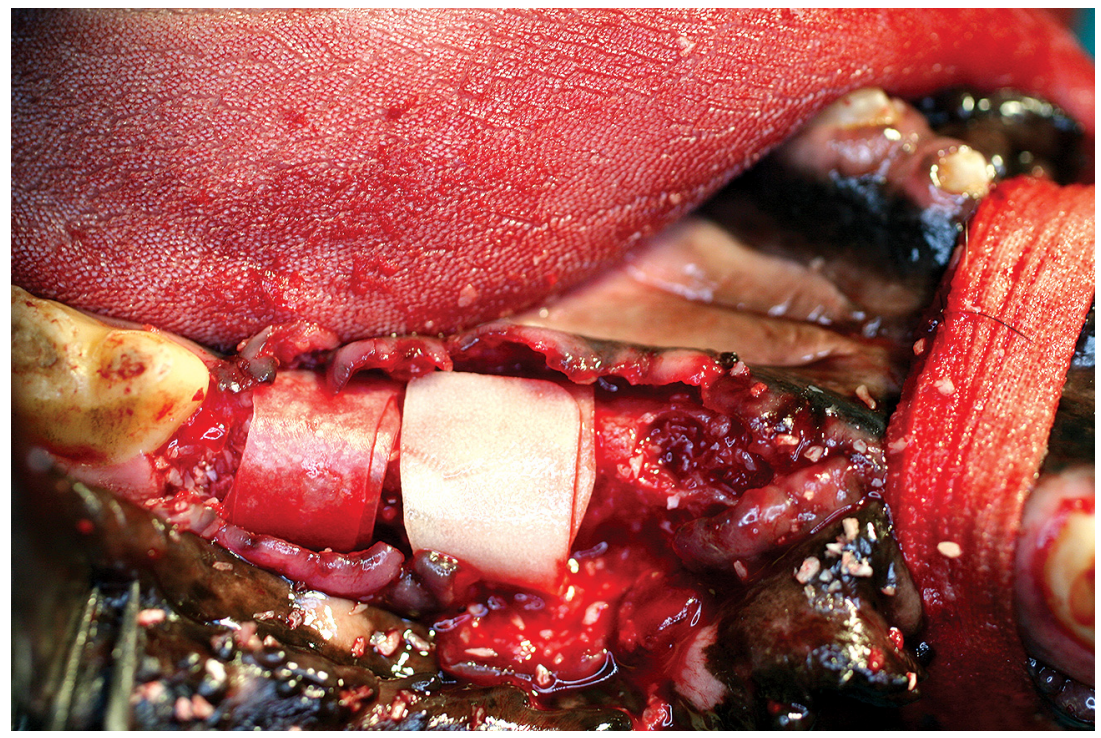

Figure 3. Post-extraction sockets, right side- double layer membrane technique; P3-collagen resorbable membrane of equine origin; P4-pericardium membrane of equine origin, (note the P2 socket filled with bone substitute, before membrane placement)

\section{The second phase of the experiment}

Two months after surgery, the first two dogs were sacrificed, four months after the intervention the other two, and six months after the intervention the last two dogs, as well. Sacrifice (euthanasia) was performed by intravenous administration of barbiturate thiopental-Na salt, by infusing $1 \mathrm{~g}$ intravenously on $30 \mathrm{~kg}$ of body weight in deep anaesthesia.

After the animals were sacrificed, mandible sections were taken from the defect sites in the form of blocks and placed in a $4 \%$ buffered formalin solution into bottles with a wide throat with a formalin: tissue ratio at 2:1. On the bottle, Roman numerals indicated the number of the experimental animal and the time of sampling. The prepared samples were sent to the Institute of Pathology, Faculty of Veterinary Medicine, University of Belgrade. The pathologist, using a special saw, intersected the received material into smaller cuts that contained the experimental jawbone defects.

\section{The third phase of the experiment}

It consisted of a histopathological analysis of the samples which was carried out at the Faculty of Veterinary Medicine, Department of Pathology.

The following histological characteristics were analysed in terms of an objective assessment of the efficacy of guided tissue regeneration and preservation of the postextraction alveoli size depending on the applied method:

1. the boundary between the soft tissue elements and the newly formed bone 
2. maturation of the newly developed bone tissue

3. presence of the newly developed blood vessels

4. presence of the osteocytes in the lacunae

5. filling of the alveola with newly developed bone tissue

6. presence of bone substitute in the alveolus

7. bone bridge formation.

The stated histological characteristics were evaluated by describing the histological samples i.e. specimens with grades 0,1 and 2 according to the criteria given in Table 1.

Table 1. Criteria for assessment of histological characteristics

\begin{tabular}{|c|c|c|c|}
\hline \multirow{2}{*}{ Histological characteristic } & \multicolumn{3}{|c|}{ Grade } \\
\hline & 0 & 1 & 2 \\
\hline $\begin{array}{l}\text { The boundary between soft-tissue } \\
\text { elements and newly formed bone }\end{array}$ & Unexpressed & $\begin{array}{c}\text { Moderately } \\
\text { expressed }\end{array}$ & Expressed \\
\hline $\begin{array}{l}\text { Maturation of the newly developed } \\
\text { bone tissue }\end{array}$ & Young, immature & Partially mature & Mature \\
\hline $\begin{array}{l}\text { Presence of the newly developed } \\
\text { blood vessels }\end{array}$ & Unexpressed & $\begin{array}{l}\text { Moderately } \\
\text { expressed }\end{array}$ & Expressed \\
\hline $\begin{array}{l}\text { Presence of the osteocytes in the } \\
\text { lacunae }\end{array}$ & Unexpressed & $\begin{array}{l}\text { Moderately } \\
\text { expressed }\end{array}$ & Expressed \\
\hline $\begin{array}{l}\text { Filling of the alveolus with newly } \\
\text { developed bone tissue }\end{array}$ & Less than $1 / 3$ & $1 / 3-2 / 3$ & More than $2 / 3$ \\
\hline $\begin{array}{l}\text { Presence of bone substitute in the } \\
\text { alveolus }\end{array}$ & Expressed & $\begin{array}{l}\text { Moderately } \\
\text { expressed }\end{array}$ & Unexpressed \\
\hline Bone bridge formation & Unexpressed & $\begin{array}{l}\text { Moderately } \\
\text { expressed }\end{array}$ & Expressed \\
\hline
\end{tabular}

For the primary data analysis, descriptive statistical methods and methods of testing statistical hypotheses have been applied. Depending on the variables type, the data descriptions were displayed as n (\%) or median (min-max). Friedman's and Wilcoxon's tests were used as the method for testing statistical hypotheses.

Statistical hypotheses were tested at a statistical significance level of 0.05 .

\section{RESULTS}

During histopathological analysis of specimens taken from the experimental regions, it was noted that there were different degrees of bone regeneration between experimental regions in which membranes were placed in one layer and those where the membranes were placed in two layers. There was no difference between membranes of different 
origin placed in the same manner. For this reason, the evaluation of methodologically determined histological characteristics, which were selected as representative in the guided bone regeneration, was performed (Tables 2, 3, 4).

Table 2. Comparative histopathological findings 2 months after the surgery

\begin{tabular}{|c|c|c|c|c|c|}
\hline \multirow{4}{*}{$\begin{array}{l}\text { Histological } \\
\text { characteristic } \\
\text { The boundary } \\
\text { between soft-tissue } \\
\text { elements and newly } \\
\text { formed bone }\end{array}$} & \multicolumn{5}{|c|}{ Findings ( 2 months after surgery) } \\
\hline & \multirow{3}{*}{$\begin{array}{l}\text { One layer } \\
\text { Two layers }\end{array}$} & \multirow{3}{*}{$\begin{array}{c}\text { Unclear } \\
6 \\
3\end{array}$} & \multirow{3}{*}{$\begin{array}{c}\text { Partly clear } \\
0 \\
3\end{array}$} & \multirow{3}{*}{$\begin{array}{c}\text { Clear } \\
0 \\
0\end{array}$} & \multirow{3}{*}{$\begin{array}{c}\mathrm{P} \\
0.083\end{array}$} \\
\hline & & & & & \\
\hline & & & & & \\
\hline \multirow{3}{*}{$\begin{array}{l}\text { Maturation of the } \\
\text { newly developed } \\
\text { bone tissue }\end{array}$} & & $\begin{array}{l}\text { Young, } \\
\text { immature }\end{array}$ & Partially mature & Mature & $\mathrm{P}$ \\
\hline & One layer & 6 & 0 & 0 & \multirow{2}{*}{1.000} \\
\hline & Two layers & 6 & 0 & 0 & \\
\hline \multirow{3}{*}{$\begin{array}{l}\text { Presence of newly } \\
\text { developed blood } \\
\text { vessels }\end{array}$} & & Unexpressed & $\begin{array}{c}\text { Moderately } \\
\text { expressed }\end{array}$ & Expressed & $\mathrm{P}$ \\
\hline & One layer & 0 & 0 & 6 & \multirow{2}{*}{1.000} \\
\hline & Two layers & 0 & 0 & 6 & \\
\hline \multirow{3}{*}{$\begin{array}{l}\text { Presence of } \\
\text { osteocytes in the } \\
\text { lacunae }\end{array}$} & & Unexpressed & $\begin{array}{c}\text { Moderately } \\
\text { expressed }\end{array}$ & Expressed & $\mathrm{P}$ \\
\hline & One layer & 0 & 5 & 1 & \multirow{2}{*}{0.564} \\
\hline & Two layers & 0 & 4 & 2 & \\
\hline \multirow{3}{*}{$\begin{array}{l}\text { Filling of the } \\
\text { alveolus with newly } \\
\text { developed bone } \\
\text { tissue }\end{array}$} & & Less than $1 / 3$ & $1 / 3-2 / 3$ & More than $2 / 3$ & $\mathrm{P}$ \\
\hline & One layer & 5 & 1 & 0 & \multirow{2}{*}{0.317} \\
\hline & Two layers & 4 & 2 & 0 & \\
\hline \multirow{3}{*}{$\begin{array}{l}\text { Presence of bone } \\
\text { substitute in the } \\
\text { alveolus }\end{array}$} & & Expressed & $\begin{array}{c}\text { Moderately } \\
\text { expressed }\end{array}$ & Unexpressed & $\mathrm{P}$ \\
\hline & One layer & 6 & 0 & 0 & \multirow{2}{*}{0.014} \\
\hline & Two layers & 0 & 6 & 0 & \\
\hline \multirow{3}{*}{$\begin{array}{l}\text { Bone bridge } \\
\text { formation }\end{array}$} & & Unexpressed & $\begin{array}{c}\text { Moderately } \\
\text { expressed }\end{array}$ & Expressed & $\mathrm{P}$ \\
\hline & One layer & 6 & 0 & 0 & \multirow{2}{*}{1.000} \\
\hline & Two layers & 6 & 0 & 0 & \\
\hline
\end{tabular}

Statistical analysis of the scores obtained by collecting the grades of predetermined histological characteristics between the groups of specimens that were taken from the experimental regions where the barrier membranes were placed in one layer compared to the specimens where the membranes were placed in two layers was performed. 
Consequently, all data were classified into two groups - one-layer and two-layer membranes. The analysed data were obtained 2, 4 and 6 months after the surgical intervention (Table 5).

Table 3. Comparative histopathological findings 4 months after the surgery

\begin{tabular}{|c|c|c|c|c|c|}
\hline \multirow{4}{*}{$\begin{array}{l}\text { Histologicalcharacteristic } \\
\text { The boundary between } \\
\text { soft-tissue elements and } \\
\text { newly formed bone }\end{array}$} & \multicolumn{5}{|c|}{ Findings (4 months after surgery) } \\
\hline & & Unclear & Partly clear & Clear & $\mathrm{P}$ \\
\hline & One layer & 1 & 5 & 0 & \multirow{2}{*}{0,414} \\
\hline & Two layers & 1 & 3 & 2 & \\
\hline \multirow{3}{*}{$\begin{array}{l}\text { Maturation of the newly } \\
\text { developed bone tissue }\end{array}$} & & $\begin{array}{l}\text { Young, } \\
\text { immature }\end{array}$ & $\begin{array}{l}\text { Partially } \\
\text { mature }\end{array}$ & Mature & $\mathrm{P}$ \\
\hline & One layer & 1 & 5 & 0 & \multirow{2}{*}{0,317} \\
\hline & Two layers & 0 & 6 & 0 & \\
\hline \multirow{3}{*}{$\begin{array}{l}\text { Presence of newly } \\
\text { developed blood vessels }\end{array}$} & & Unexpressed & $\begin{array}{l}\text { Moderately } \\
\text { expressed }\end{array}$ & Expressed & $\mathrm{P}$ \\
\hline & One layer & 0 & 0 & 6 & \multirow{2}{*}{1,000} \\
\hline & Two layers & 0 & 0 & 6 & \\
\hline \multirow{3}{*}{$\begin{array}{l}\text { Presence of osteocytes in } \\
\text { the lacunae }\end{array}$} & & Unexpressed & $\begin{array}{l}\text { Moderately } \\
\text { expressed }\end{array}$ & Expressed & $\mathrm{p}$ \\
\hline & One layer & 0 & 2 & 4 & \multirow{2}{*}{1,000} \\
\hline & Two layers & 0 & 2 & 4 & \\
\hline \multirow{3}{*}{$\begin{array}{l}\text { Filling of the alveolus with } \\
\text { newly developed bone } \\
\text { tissue }\end{array}$} & & $\begin{array}{c}\text { Less than } \\
1 / 3\end{array}$ & $1 / 3-2 / 3$ & $\begin{array}{l}\text { More than } \\
2 / 3\end{array}$ & $\mathrm{P}$ \\
\hline & One layer & 3 & 3 & 0 & \multirow{2}{*}{0,157} \\
\hline & Two layers & 1 & 5 & 0 & \\
\hline \multirow{3}{*}{$\begin{array}{l}\text { Presence of bone substitute } \\
\text { in alveolus }\end{array}$} & & Expressed & $\begin{array}{l}\text { Moderately } \\
\text { expressed }\end{array}$ & Unexpressed & $\mathrm{P}$ \\
\hline & One layer & 0 & 0 & 6 & \multirow{2}{*}{1,000} \\
\hline & Two layers & 0 & 0 & 6 & \\
\hline \multirow{3}{*}{ Bone bridge formation } & & Unexpressed & $\begin{array}{l}\text { Moderately } \\
\text { expressed }\end{array}$ & Expressed & $\mathrm{P}$ \\
\hline & One layer & 0 & 6 & 0 & \multirow{2}{*}{0,083} \\
\hline & Two layers & 0 & 3 & 3 & \\
\hline
\end{tabular}


Table 4. Comparative histopathological findings 6 months after the surgery

\begin{tabular}{|c|c|c|c|c|c|}
\hline \multirow{4}{*}{ 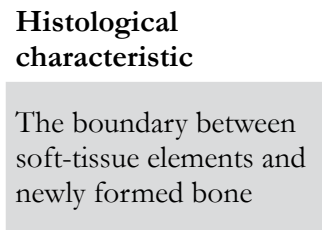 } & \multicolumn{5}{|c|}{ Findings (6 months after surgery) } \\
\hline & & Unclear & Partly clear & Clear & $\mathrm{P}$ \\
\hline & One layer & 0 & 2 & 4 & 0157 \\
\hline & Two layers & 0 & 0 & 6 & 0.151 \\
\hline \multirow{3}{*}{$\begin{array}{l}\text { Maturation of the newly } \\
\text { developed bone tissue }\end{array}$} & & $\begin{array}{l}\text { Young, } \\
\text { immature }\end{array}$ & $\begin{array}{l}\text { Partially } \\
\text { mature }\end{array}$ & Mature & $\mathrm{P}$ \\
\hline & One layer & 0 & 1 & 5 & \multirow{2}{*}{0.317} \\
\hline & Two layers & 0 & 0 & 6 & \\
\hline \multirow{3}{*}{$\begin{array}{l}\text { Presence of newly } \\
\text { developed blood vessels }\end{array}$} & & Unexpressed & $\begin{array}{c}\text { Moderately } \\
\text { expressed }\end{array}$ & Expressed & $\mathrm{P}$ \\
\hline & One layer & 0 & 0 & 6 & \multirow{2}{*}{1.000} \\
\hline & Two layers & 0 & 0 & 6 & \\
\hline \multirow{3}{*}{$\begin{array}{l}\text { Presence of osteocytes } \\
\text { in the lacunae }\end{array}$} & & Unexpressed & $\begin{array}{c}\text { Moderately } \\
\text { expressed }\end{array}$ & Expressed & $\mathrm{P}$ \\
\hline & One layer & 0 & 0 & 6 & \multirow{2}{*}{1.000} \\
\hline & Two layers & 0 & 0 & 6 & \\
\hline \multirow{3}{*}{$\begin{array}{l}\text { Filling of the alveolus } \\
\text { with newly developed } \\
\text { bone tissue }\end{array}$} & & Less than $1 / 3$ & $1 / 3-2 / 3$ & More than $2 / 3$ & $\mathrm{P}$ \\
\hline & One layer & 0 & 2 & 4 & \multirow{2}{*}{0.317} \\
\hline & Two layers & 0 & 1 & 5 & \\
\hline \multirow{3}{*}{$\begin{array}{l}\text { Presence of bone } \\
\text { substitute in the alveolus }\end{array}$} & & Expressed & $\begin{array}{c}\text { Moderately } \\
\text { expressed }\end{array}$ & Unexpressed & $\mathrm{P}$ \\
\hline & One layer & 0 & 0 & 6 & \multirow{2}{*}{1.000} \\
\hline & Two layers & 0 & 0 & 6 & \\
\hline \multirow{3}{*}{ Bone bridge formation } & & Unexpressed & $\begin{array}{c}\text { Moderately } \\
\text { expressed }\end{array}$ & Expressed & $\mathrm{P}$ \\
\hline & One layer & 0 & 4 & 2 & \multirow{2}{*}{0.046} \\
\hline & Two layers & 0 & 0 & 6 & \\
\hline
\end{tabular}

Table 5. Mid-range estimates of histological characteristics of membranes placed in one and two layers

\begin{tabular}{lcccc}
\hline Grade scoring of histological characteristics & Med & Min & Max \\
\hline \multirow{2}{*}{2 months } & One layer & 3.0 & 3.0 & 4.0 \\
& Two layers & 4.5 & 4.0 & 7.0 \\
\hline \multirow{2}{*}{4 months } & One layer & 9.0 & 8.0 & 10.0 \\
& Two layers & 10.0 & 9.0 & 12.0 \\
\hline \multirow{2}{*}{6 months } & One layer & 12.5 & 11.0 & 14.0 \\
& Two layers & 14.0 & 13.0 & 14.0 \\
\hline
\end{tabular}




\section{Time differences}

There was a significant increase in the median total score occurring during the $6^{\text {th }}$ month in relation to the $2^{\text {nd }}$ month $(p=0.026)$ and the $4^{\text {th }}$ month $(p=0.026)$ from the placement of the single-layered membranes, as well as during the $4^{\text {th }}$ month in respect to the $2^{\text {nd }}$ month $(\mathrm{p}=0.024)$.

There was a statistically significant difference in the median values of the total histological characteristics of the two-layered membranes during the examined time period, also. A statistically significant difference in median total score occurred in the $6^{\text {th }}$ month compared to the $2^{\text {nd }}(p=0.026)$ and the $4^{\text {th }}$ month $(p=0.027)$ since the membrane placement, as well as during the $4^{\text {th }}$ month in respect to the $2^{\text {nd }}$ month (Table 5).

The median value of the total sum in the $2^{\text {nd }}$ month for a single-layer membrane was 3.0 (range, 3.0-4.0), while for the double-layer membrane the median value was 4.5 (range, 4.0-7.0).

There was a statistically significant difference in the median total sum between the examined groups (Table 5).

The median value of the total sum in the $4^{\text {th }}$ month for a single-layer membrane was 9.0 (range, 8.0-10.0), while for the double-layer membrane the median value was 10.0 (range, 9.0-12.0). There was a statistically significant difference in the median total sum between the examined groups (Table 5).

The median value of the total sum in the $6^{\text {th }}$ month for a single-layer membrane was 12.5 (range, 11.0-14.0), while for the double-layer membrane the median value was 14 (range, 13.0-14.0). There was a statistically significant difference in the median total sum between the examined groups (Table 5).

\section{DISCUSSION}

Healing of the tooth extraction wound is the physiological process of bone tissue reparation and regeneration, which differs from the healing process elsewhere in the body. After tooth extraction, at the site of the extraction wound, the processes of healing immediately commences in the sense of bleeding from the blood vessels of the alveolar bone and formation of a blood clot in the alveolar socket. The created coagulum, which protects the injured and bare alveolar bone, represents the barrier to the harmful effects of the environment and, in the later stages of healing, serves as a stimulus for ingrowth of young blood vessels followed by formation of granulation tissue.

The main problem that inevitably occurs after tooth extraction is resorption of the alveolar ridge, which is conditioned by the loss of the basic, supporting role of alveolar bone at the extraction site. Recently, for the purpose of preserving the alveolar ridge after tooth extraction, the therapeutic procedure for preserving the post-extraction 
alveolus has been suggested, which implies filling the post-extraction alveolus with various bone substitutes and covering it with resorbable barrier membranes. Bone substitutes should enable the creation of a better-quality bone at the extraction site and provide support to membranes so that the membranes barrier function, in terms of demarcation of the connective-epithelial tissue elements.

Different authors have described the method of guided bone regeneration proposed for targeted healing of bone defects in jaws. In 1994, Schenk et al. [26] examined the guided bone regeneration in mandibular defects in dogs. For this purpose, the barrier capabilities of two types of anti-corrosive membranes made of e-PTFE were examined. Histological tests have shown that bone regeneration, once started, is a programmed, progressive process that goes through a series of maturation stages. Furthermore, the authors discovered that the experimental regions in which the barrier membrane was used showed a higher degree of bone regeneration compared to non-membrane regions.

A small number of scientists examined the role of collagen membranes thickness in the bone defects ossification both in the procedures of preserving alveoli and in guided bone regeneration in general. In their work in 2012, Bubalo et al. [27] examined the effect of collagen membranes of different thickness on regeneration of defects in the dog mandible. They have analysed histologically the quality of newly developed bone at sites where artificially made defects were covered with resorbable membranes of different thickness. Their results, as it was expected, proved that in areas where guided bone regeneration with barrier membranes was applied, there was a higher quality bone tissue compared to the regions which were left to spontaneously heal. By analysing the specimens taken from the experimental regions in which the membranes of different thicknesses were placed, the authors concluded that the thickness of the membrane has an effect on bone defect healing. Actually, their results show that the use of identical membranes of higher thickness results in faster creation of mature bone tissue compared to membranes of lesser thickness.

In this experimental study we have analysed the influence of three types of bioresorbable membranes (collagen membrane of porcine origin - Bio-Gide, Geistlich, Switzerland; collagen membrane of equine origin - OXâ, Osteoxenon, Bioactiva, Italy; pericardial equine membrane - HEART, Osteoxenon, Bioactiva, Italy ) in combination with a substitute of horse origin (OSP-OX32, Osteoxenon, Bioactiva Italy) on the regeneration of bone defects caused by tooth extraction. The membranes were placed in one or two layers as to examine a hypothetically set theory that the application of collagen membranes placed in two layers achieves a higher degree of bone regeneration compared to the membranes placed in one layer, and within the framework of bone regeneration procedures.

A statistical comparison of middle values of total histological characteristics of specimens was performed during 2, 4 and 6 months after surgical intervention. The statistical analysis confirmed the pathohistological observations - there was a 
statistically significant difference in middle values of recent histological characteristics in all examined periods in favour of membranes placed in two layers. A higher degree of bone regeneration was achieved after application of membranes placed in two layers. When comparing the total score of histological characteristics during the examined period for each group (one-layer and two-layers), it was noted that there was a statistical significance of data obtained after 4 months in compared to those obtained after the $2^{\text {nd }}$ month, and for data obtained after 6 months compared to those obtained after the $4^{\text {th }}$ month. However, the increased bone regeneration rate was achieved also when the membranes were placed in one layer.

Histological specimens from experimental regions for each of the listed histological characteristics were also statistically analysed. The statistical significance was observed in the $2^{\text {nd }}$ month where there was a less expressed presence of bone substitute in alveoli covered with double-layer membranes and in the $6^{\text {th }}$ month at sites where membranes were placed in two layers, the bone bridge connecting the lingual and buccal alveolar bone was more expressed. However, many characteristics were close to the significance threshold, always in favour of membranes placed in two layers. Although it was not possible to detect statistical significance due to the relatively small sample, a tendency of faster changes in the direction of a higher bone regeneration in the experimental regions where the membranes were placed in two layers was obvious.

Although the manufacturers of resorbable membranes examined in this study suggest a slightly longer period of resorption, our results unambiguously showed that no membranes remnants were detected within 4 months post-membrane placement. Resorption was complete in the first 4 months (Figures 4 and 5). The question is whether the extended period of membrane resorption increased the degree of bone regeneration. The results of this study coincide with the results published in 2001 by Owens and Yukna [28]. They examined the resorption rate of resorbable membranes of bovine, porcine and human origins placed on dogs' palatines - 4 months after placing the membrane, they were completely resorbed. Similar results were published in 2009 by Kozlovsky et al. [29], who examined the degree of degeneration of collagen membranes of bovine origin (Bio-Gide) placed in one and two layers on the rat calvaria. They found fragments of the membrane placed in two layers even after 9 weeks and concluded that the single-layer membrane could not perform its function for a longer period of time.

In our study, 4 months after tooth extraction, in all experimental regions, a new bone formation was created in the form of a bone bridge that connects the limbs of the preserved alveolar bone. Six months after the surgery the bone bridge was even more developed (Figures 5 and 6). This coincides with the results of Cardaropoli et al. [30] who state that the cortical edge after tooth extraction in the dog is formed after 3 months. Our results show that the formation of a bone bridge was more expressed at places where the alveoli were covered with two-layer membranes. A greater bone bridge width would presumably contribute to a greater primary stability in possible implantation procedures. 
Observing the boundary between the submucosal connective tissue and the surface of the alveolus, we found that it was clearer in the experimental regions were alveoli are covered by membranes placed in two layers regardless of the time elapsed from the surgical intervention. Similar results have also been cited by Bubalo et al. [27], who have obtained a sharper boundary toward the bone tissue, with minor soft tissue ingrowth into the bone, at sites where bone defects were covered with thicker membranes.

In this study, a bone substitute of equine origin with a preserved collagen component in it was used to fill the extraction alveoli. Histolopatological results show that the presence of bone substitutes was evident only on specimens 2 months after intervention and with a much greater quantity in the one layer membranes, whereas in alveoli covered with two layers membranes, resorption has already begun (Figure 4).

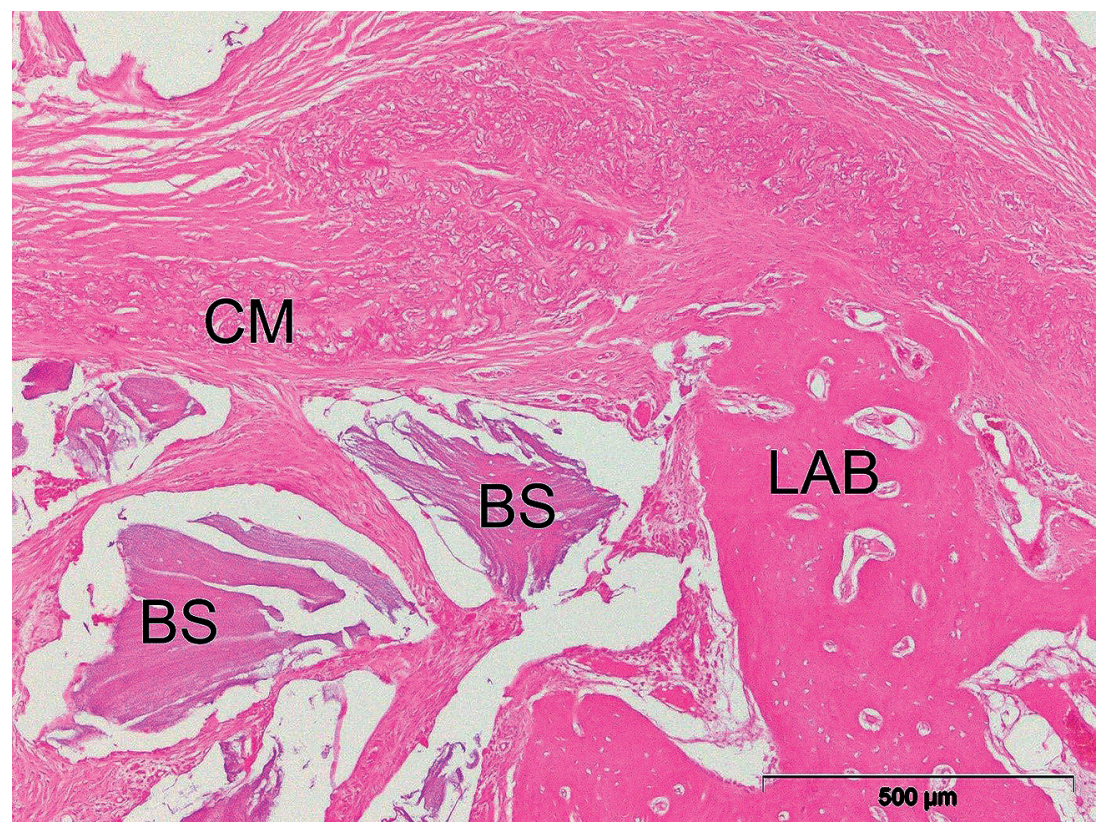

Figure 4. Preserved post-extraction socket with bone substitute and collagen membrane of porcine origin, single layer, 2 months after the surgery. $\mathrm{CM}$ - collagen membrane, BS - bone substitute, LAB - lingual alveolar bone. (HEx100)

Therefore, it was concluded that the reparatory processes and thus the substitute resorption were more intense in alveoli covered with two layers membranes. After 4 months there was no longer any bone substitute in all post-extraction alveoli. Although the manufacturer states that the resorption of this type of substitute completely ends 4 to 6 months after implantation, the results of this study show a slightly shorter period of degradation - from 2 to 4 months (Figure 5), probably due to the fact that physiological processes of reparation and regeneration are faster in dogs than in humans. 


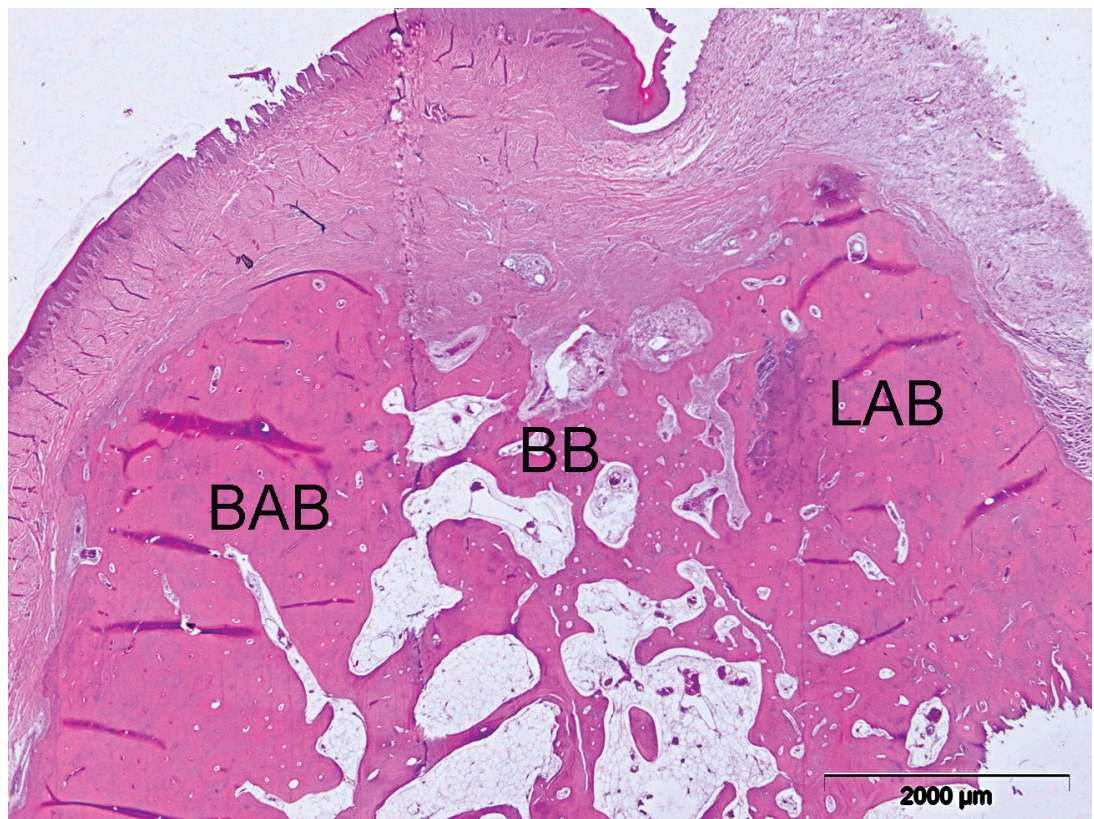

Figure 5. Preserved post-extraction socket with bone substitute and collagen membrane of porcine origin, single layer, 4 months after the surgery. BAB - buccal alveolar bone, BB - bone bridge, LAB - lingual alveolar bone. (HE x 20)

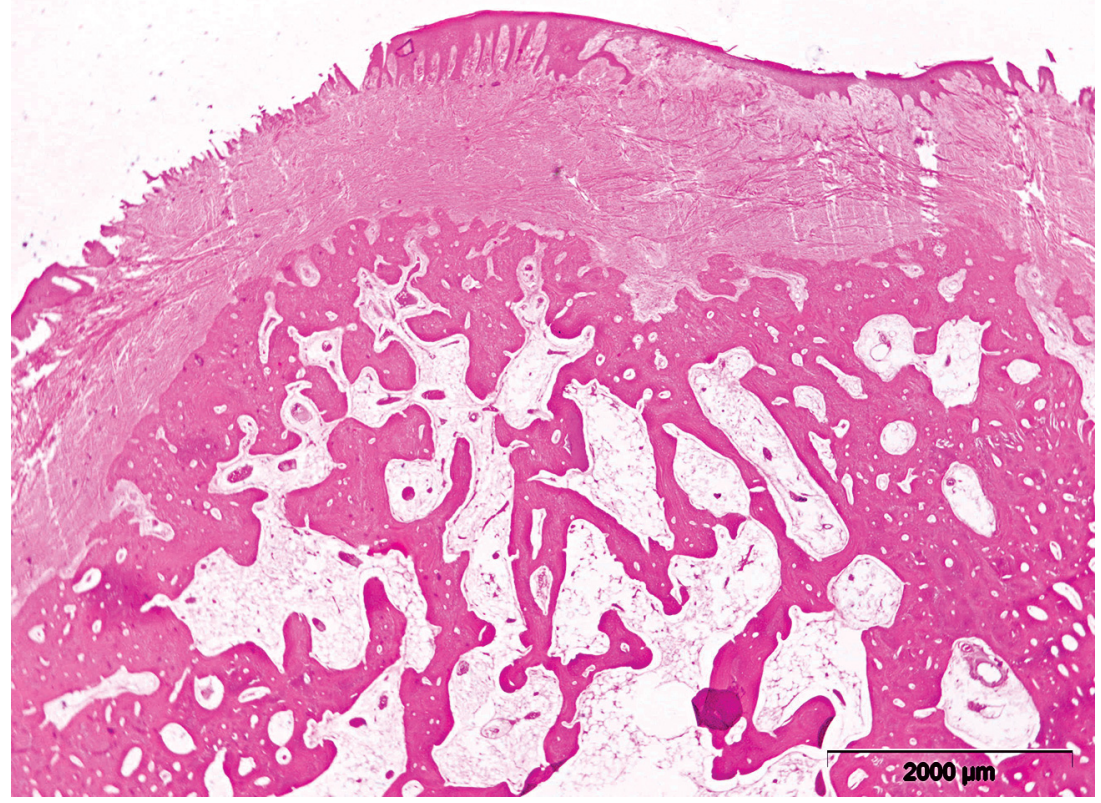

Figure 6. Preserved post-extraction socket with bone substitute and pericardial membrane of equine origin, double layer, 6 months after the surgery. Post-extraction socket is hardly recognizable. Newly formed bone trabeculae and bone marrow have filled the socket completely. There is no evidence of either bone substitute or membrane. (HE x 20) 


\section{CONCLUSION}

Based on the obtained results, it can be concluded that covering the post-extraction alveoli, filled with bone substitute, with resorbable membranes placed in two layers results in a higher degree of bone regeneration compared to the use of resorbable membranes placed in one layer. There is no significant difference in the degree of bone regeneration within the preservation of alveoli procedures between collagen membranes of porcine origin and collagen and pericardial membranes of equine origin.

\section{Authors' contributions}

ĐF, MB and LZ participated in the sequence alignment and drafted the manuscript. MD participated in the pathohystological analysis. BZ participated in the design of the study and performed the statistical analysis. DD, ZT and BM conceived of the study, and participated in its design and coordination and helped to draft the manuscript. All authors read and approved the final manuscript.

\section{Declaration of conflicting interests}

The author(s) declared no potential conflicts of interest with respect to the research, authorship, and/or publication of this article.

\section{REFERENCES}

1. Araujo MG, Lindhe J: Dimensional ridge alterations following tooth extraction. An experimental study in the dog. J Clin Periodontology 2005;32:212-218.

2. Chappuis, V, Engel O, Reyes M, Shahim K, Nolte LP, Buser D: Ridge alterations postextraction in the esthetic zone: A 3D analysis with CBCT. J Dent Res 2013;9:195S-201S.

3. Llanos AH, Sapata VM, Jung RE, Hämmerle CH, Thoma DS, César Neto JB, Pannuti CM, Romito GA: Comparison between two bone substitutes for alveolarridge preservation after tooth extraction: Cone-beamcomputed tomography results of a non-inferiorityrandomized controlled trial. J Clin Periodontol 2019;46:373-381.

4. Bubalo M. Uticaj resorptivne demineralizovane membrane humanog i bovinog porekla, različite $\mathrm{i}$ iste debljine na osifikaciju koštanih defekata. Doktorska disertacija, 2012., K.Mitrovica

5. Hoffmann O, Bartee BK, Beaumont C, Kasaj A, Deli G, Zafiropoulos GG: Alveolar bone preservation in extraction sockets using non-resorbable dPTFE membranes: a retrospective non-randomized study. J Periodontol 2008;79:1355-1369

6. Luczyszyn SM, Papalexiou V, Novaes AB, Grisi MFM, Souza SLS, Taba M: Acellular dermal matrix and hydroxyapatite in prevention of ridge deformities after tooth extraction. Implant Dent 2005;14:2:176-184 
7. Lasella JM, Greenwell H, Miller RL, Hill M, Drisko C, Bohra AA, Scheetz JP: Ridge preservation with freeze-dried bone allograft and a collagen membrane compared to extraction alone for implant site development: a clinical and histologic study in humans. J Periodontol 2003;74:7:990-999

8. Fickl S, Zuhr O, Wachtel H, Stappert CFJ, Stein JM, Hurzeler MB: Dimensional changes of the alveolar ridge contour after different socket preservation techniques. J Clin Periodontol 2008;35:10:906-913

9. Nemcovsky CE, Serfaty V. Alveolar ridge preservation following extraction of maxillary anterior teeth. Report on 23 consecutive cases. J Periodontol 1996;67:4:390-395

10. Brugnami F, Then PR, Moroi H, Leone CW: Histologic evaluation of human extraction sockets treated with demineralized freeze-dried bone allograft (DFDBA) and cell occlusive membrane. J Periodontol 1996;67:8:821-825

11. Sclar AG: Preserving alveolar ridge anatomy following tooth removal in conjunction with immediate implant placement. The Bio-Col technique. Atlas Oral Maxillofac Surg Clin North Am 1999;7:2:39-59

12. Wang HL, Tsao YP: Mineralized bone allograftplug socket augmentation: rationale and technique Implant Dent. 2007;16:1:33-41

13. Iasella JM, Greenwell H, Miller RL, Hill M, Drisko C, Bohra, Scheetz JP: Ridge preservation with freeze-dried bone allograft and a collagen A.A. membrane compared to extraction alone for implant site development: a clinical and histologic study in humans. J Periodontol 2003;74:990-999

14. Kesmas S, Swasdison S, Yodsanga S, Sessirisombat S, Jansisyanont P: Esthetic alveolar ridge preservation with calcium phosphate and collagen membrane: Preliminary report. Oral Surg Oral Med Oral Pathol Oral Radiol Endod 2010; 110:24-36

15. Gholami GA, Najafi B, Mashhadiabbas F, Goetz W, Najafi S: Clinical, histologic and histomorphometric evaluation of socket preservation using a syntetic nanocrystalline hydroxyapatite in comparison with a bovine xenograft: a randomize clinical trial. Clin Oral Impl Res 2012;23:1198-1204

16. Barone A, Aldini NN, Fini M, Giardano R, Calvo Guirado JL, Covani U: Xenograft versus extraction alone for ridge preservation after tooth removal: a clinicaland histomorfometric study. J Periodontol 2008;79:1370:1377

17. Simon BI, Von Hagen S, Deasy MJ, Faldu M, Resnansky D: Changes in alveolar bone height and width following ridge augmentation using bone graft and membranes. J Periodontol 2000;71:11:1774-1791

18. Artzi Z, Tal H and Dayan D: Porous bovine bone mineral in healing of human extraction sockets. Part 1: histomorphometric evaluations at 9 months. J Periodontol 2000;71:6:10151023

19. Artzi Z, Tal H, Dayan D: Porous bovine bone mineral in healing of human extraction sockets Part 2: histochemical observations at 9 months. J Periodontol 2001;72:2:152-159

20. Araujo M., Linder E, Wennstrom J, Lindhe J: The influence of Bio-Oss collagen on healing of an extraction socket: an experimental study in the dog. Int J Periodontics Restorative Dent 2008;28:2:123-135

21. Araujo M, Linder E, Lindhe J: Effect of a xenograft on early bone formation in extraction sockets: an experimental study in dog. Clin Oral Impl Res 2009;20:1:1-6

22. Luttikhuizen DT, Harmsen MC, Van Luyn MJA: Cellular and molecular dynamics in the foreign body reaction. Tissue Eng 2006;12:7:1955-1970 
23. Wang RE, Lang NP: New insights into ridge preservation after tooth extraction. Clin Oral Impl Res 2012;23(6):147-156

24. Buser D: 20 Years of guided bone regeneration in implant dentistry. Quintessence Publishing Company 2009.

25. Bisenlechner D, Kantor M, Tangel S, Tepper G, Zechner W, Haas R, Watzek G: Alveolar ridge augmentation with a prototype trilayer membrane and various bone grafts: a histomorphometric study in baboons. Clin Oral Impl. Res 2005;16:220-227

26. Schenk RK, Buser D, Hardwick WR, Dahlin C: Healing pattern of bone regeneration in membrane-protected defects: a histologic study in the canine mandible. Int J Oral Maxillofac Implants 1994;9(1):13-29

27. Bubalo M, Lazic Z, Matic S, Tatic Z, Milovic R, Petkovic A, Djurdjevic D, Loncarevic S: The impact of thickness of resorbable membrane of human origin on the ossification of bone defects: a pathohistologic study. Vojnosanit Pregl 2012;69(12):1076-1083

28. Owens K, Yukna RA. Collagen membrane resorption in dogs: a comparative study. Implant Dent 2001;10(1):49-58

29. Kozlovsky A, Aboodi G, Moses O, Tal H, Artzi Z, Weinreb M, Nemcovsky CE: Biodegradation of a resorbable collagen membrane (Bio-gide) applied in a double-layer technique in rats. Clin Oral Impl Res 2009;20:1116-1123

30. Cardaropoli G, Araujo M, Lindhe J: Dynamics of bone tissue formation in tooth extraction sites. An experimental study in dogs. J Clin Periodontology 2003;30:809-818.

\title{
UTICAJ KOLAGENIH MEMBRANA POSTAVLJENIH U DVA SLOJA NA OSIFIKACIJU POSTEKSTRAKCIONIH ALVEOLA - PATOHISTOLOŠKA EKSPERIMENTALNA STUDIJA NA PSIMA
}

\author{
DUBOVINA Dejan, BUBALO Marija, MIHAILOVIĆ Branko, TATIĆ Zoran, \\ MARINKOVIĆ Darko, BUKUMIRIĆ Zoran, ĐORĐEVIĆ Filip, LAZIĆ Zoran
}

Prezervacija postekstrakcionih alveola predstavlja preventivni oralnohirurški postupak u cilju očuvanja dimenzija alveolarnog grebena nakon ekstrakcije zuba. Prema dostupnoj literaturi, primena vođene regeneracije kosti u tu svrhu je apsolutno opravdana. Cilj ove studije bio je da ispita efekat resorptivih kolagenih membrana postavljenih $u$ dva sloja u odnosu na postavljanje membrane u jednom sloju na stepen regeneracije kosti nakon vađenja zuba. Ova eksperimentalna studija izvedena je na šest odraslih pasa. U prvoj fazi istraživanja ekstrahirana su sa četiri premolara na obe strane donje vilice. Nakon standardizacije borerom za kost i punjenja koštanim zamenikom, postekstrakcione alveole su prekrivane kolagenim membranama. Membrane na levoj strani su postavljane u jednom sloju, a na desnoj u dva sloja. Nakon različitih perioda praćenja psi su žrtvovani i sprovedena je histopatološka analiza dobijenih uzoraka. Postojala je razlika u stepenu koštane regeneracije između eksperimentalnih regija u 
kojima su membrane postavljane u jednom sloju i onih gde su membrane postavljane u dva sloja. Nije bilo razlike između membrana različitog porekla postavljenih na isti način. Postupak prekrivanja postekstrakcionih alveola ispunjenih koštanim zamenikom i resorptivnim membranama postavljenim u dva sloja, rezultira višim stepenom regeneracije kosti u poređenju sa upotrebom resorptivnih membrana postavljenih $u$ jednom sloju. 